\title{
MOLECULAR APPROACH TO THE ETIOLOGY OF HUMAN CANCER
}

\author{
S. SPIEGELMAN \\ Institute of Cancer Research, College of Physicians and Surgeons, Columbia University, New York City 1032, USA
}

\begin{abstract}
DNA-RNA hybridization was used to explore whether human neoplasias contain RNA molecules having sequence homologies to those of the RNA tumor viruses known to cause similar diseases in animals. The pattern of specific RNA's found in the human tumors showed a remarkable concordance with the predictions deducible from the animal systems. Thus, human breast cancer contains RNA homologous only to that of the murine mammary tumor virus. Human leukemias, sarcomas, and lymphomas (including Hodgkin's and Burkitt's lymphomas) all contain RNA with sequence homology to the murine leukemia virus and not to murine mammary tumor virus RNA. Finally, as in the case of the mouse, none of the human tumors examined contains RNA in sequence to that of the avian myeloblastosis virus. The RNA detected in all of the human neoplasias was demonstrated to be of high molecular weight $\left(1 \times 10^{7}\right.$ daltons) and encapsulated with a reverse transcriptase in particles having densities between 1.16 and $1.19 \mathrm{~g} / \mathrm{ml}$. Further, the RNA of these human tumor particles was related in sequence to the murine viruses that cause the corresponding neoplasias in mice. Thus, four features diagnostic for the murine oncogenic viruses are satisfied by the particles found in the human cancers. Finally, it was shown by "recycling" experiments that the DNA from human leukemic cells and from lymphomatous tissue contained particle-related sequences that could not be detected in normal DNA. This finding was further substantiated by studies with identical twins in which it was shown that the leukemic twin contained particle-related sequences that could not be detected in the leukocytes of his identical healthy sibling. These findings are inconsistent with hypotheses that require chromosomal transmission in the germ line of complete copies of the information required to produce malignancy and the associated virus particles.
\end{abstract}

\section{INTRODUCTION}

One of the most striking characteristics of the cancer cell is that the malignant state is transmissible to its progeny. Over the years a number of explanations have been proposed to explain the cellular heritability of the cancer state. Some of these hypothetical mechanisms are listed in Table 1, along with their predicted consequences for sequence changes detectable by the technique of nucleic acid hybridization. It should be noted that the methods generally employed to detect the heteroduplexes require stretches of complementary homology involving 50 or more hydrogen-bonded base pairs. Thus, for example, somatic mutations in a structural or regulatory gene are not likely to produce more than a few base changes and therefore could not be detected by molecular hybridization procedures. The same is true for chromosomal translocations or inversions since they would generate only minor sequence differences. The third mechanism of chromosomal imbalance resulting from the loss or extra duplication of one or more of the chromosomal complements can lead only to the gain or loss of pre-existent sequences.

The fourth mechanism is a possibility that emerged from the study of the so-called "lysogenizing" or "transducing" phages. Here one has a phenomenon in which the virus inserts its genetic information into the genome of the host cell. If the virus involved is a DNA agent, there are no chemical problems posed and the mechanism of insertion of DNA into DNA via prior circularization is quite well understood. ${ }^{9}$ If, however, the virus involved is an RNA virus, then a mechanism is required for making a DNA transcript of the viral RNA, which can then be inserted into the DNA. This hypothesis then becomes formally identical to the early "provirus" hypothesis of Temin, ${ }^{41}$ which ultimately led to the discovery of "reverse transcriptase" in the RNA tumor viruses. ${ }^{4,42}$

The fifth hypothesis involves a heritable phenotypic modification unaccompanied by any change in the genetic information, quite analogous to what is presumed to occur in cellular differentiation. Here we assume the preexistence of a silent malignant segment of genetic information that can undergo a self-reinforcing derepression. It is not too difficult to devise such mechanisms. For example, one could assume that when the repressor protein is free from the DNA, it can serve as a necessary functional subunit of an enzyme complex that synthesizes a molecule that can both stabilize the enzyme complex and also act as an inducer to derepress the malignant segment. Thus any intrinsic or extrinsic factor that dislodges the original repressor protein will initiate a chain of events that will ensure that the depression will be maintained and cytoplasmically transmitted. If the repressed malignant segment codes for an RNA tumor virus, the fifth hypothesis becomes equivalent to the "virogene-oncogene" hypothesis of Todaro and Huebner. ${ }^{43}$

In what follows we describe experiments to decide amongst these alternatives for particular human neoplasias. There are several aspects of this type of analysis that merit explicit expression. The five mechanisms noted do not constitute an exhaustive list of all possibilities. They do have the advantage of being sufficiently precise to permit the deduction of their consequences. Further, they are not mutually exclusive in either a general or a particular sense. Various forms of cancer in the same animal might be mediated by different mechanisms and similarly for the same cancer in divergent animals. Finally, more than one of the mechanisms listed might be implicated in the occurrence of one and the same neoplasia. Thus, all one can experimentally hope to decide is whether one of the mechanisms is involved in a specific neoplasia in a particular animal. Support for one mechanism in a particular instance does not eliminate the others; it simply says they cannot be the sole cause.

The fourth mechanism is unique in making two 
Table 1. Hypotheses of cancer etiology and their DNA sequence consequences

\begin{tabular}{|c|c|c|}
\hline Hypothesis. & Mechanism & $\begin{array}{l}\text { Sequence Change } \\
\text { Detectable by } \\
\text { Hybridization } \\
\end{array}$ \\
\hline 1. Mutation & $\begin{array}{c}\text { Individual Base Changes } \\
\text { in Structural or } \\
\text { Regulatory Genes }\end{array}$ & None \\
\hline $\begin{array}{l}\text { 2. Chromosomal } \\
\text { Rearrangement }\end{array}$ & $\begin{array}{c}\text { Translocation, inversion } \\
\text { etc. }\end{array}$ & None \\
\hline $\begin{array}{l}\text { 3. Chromosomal } \\
\text { Imbalance }\end{array}$ & Loss or Duplication & $\begin{array}{l}\text { Loss or gain of } \\
\text { old sequences }\end{array}$ \\
\hline 4. Transduction & Insertion of Viral Genes & $\begin{array}{l}\text { Gain of new } \\
\text { sequences }\end{array}$ \\
\hline 5. Phenotypic & $\begin{array}{l}\text { Self-reinforcing derepression } \\
\text { of silent genes }\end{array}$ & None \\
\hline
\end{tabular}

experimentally useful predictions. It is the only one that demands the active participation of a viral agent at some point of the carcinogenic process. It is also the only one that predicts the acquisition of new and viral-related information by the malignant cell. It is evident that any attempt to examine human cancer from this point of view must start with a search for evidence of viral agents in the human disease.

\section{ANIMAL VIRAL ONCOLOGY}

We had perhaps best begin by explicitly noting a bias stemming from our previous experiences with RNA viruses and our assessment of the information available on the relation between viruses and cancer. Both DNA and RNA tumor viruses have been identified as etiologic agents in laboratory experiments. However, we decided to concentrate our initial efforts on the RNA oncornaviruses, a choice made for two reasons. One is that the RNA oncogenic agents predominate quantitatively in the animal systems studied. The second is that it is the RNA tumor viruses that have been repeatedly demonstrated to cause tumors in their indigenous hosts. Thus, from the viewpoint of the natural history of the disease, the RNA oncogenic viruses appeared to us as the more probable "natural" candidates for etiologic agents of cancer in the animal kingdom, including man.

Over the past $50 \mathrm{yr}$, animal viral oncology has amassed a considerable fund of information concerning the so-called B-type and C-type RNA tumor viruses. ${ }^{15}$ These agents have been implicated in a variety of cancers in a wide spectrum of animals. In many instances, convincing evidence has been obtained by inoculation of purified viruses into susceptible animals in experiments that satisfy Koch's criteria for the identification of the causative agent of a particular disease.

Our working assumption was based on the improbability that cancer in man would have so different an etiological basis that the information provided by animal experiments would be irrelevant to the human disease. If this be the case, one might well wonder why it has been so difficult to provide acceptable evidence for a viral agent in human cancer. A plausible explanation emerges from an examination of the historical development of animal viral oncology. Forty to fifty years ago, it was as difficult to identify viruses in animal tumors as it is today in the human neoplasias. The experimental picture changed dramatically as the result of a decision by geneticists that had a profound serendipic effect on the subsequent development of cancer research. A group of investigators, including Little, Strong, MacDowell and Furth, ${ }^{15}$ developed highly inbred strains of mice, some of which were characterized by a high frequency of various neoplasias, including mammary tumors, leukemias, etc. The intent was of course to mate these with low frequency strains and from the distribution of the characteristic cancer phenotype deduce the genetic factors underlying susceptibility and resistance to the disease. What occurred unexpectedly, however, was that in the course of developing the inbred stocks of high cancer frequency,a genetic background was inadvertently created permitting the tumor viruses to multiply to levels that made their identification inevitable. This, along with the introduction in 1951 by Gross of neonatal mice for virus assay, did much to open up the field of viral oncology.

Those who are concerned with human neoplasias are for the most part faced with the same difficulties encountered by the early animal oncologists before inbred strains were available. It follows that the detection of putative human viral agents requires more sensitive devices than those which sufficed to establish their presence in the inbred animal systems. In searching for such tools, we quite naturally turned to molecular hybridization and the other methodologies developed by molecular biologists in the past several decades.

Our investigations evolved through a number of stages that are conveniently identified by the questions we posed sequentially for experimental resolution as our studies progressed.

(1) Do human neoplasias contain RNA molecules possessing detectable homology to the RNA of tumor viruses known to cause similar cancers in animals?

(2) If a positive outcome is obtained, do the RNA molecules identified in tumors possess the size and physical association with reverse transcriptase that characterize the RNA of the animal oncornaviruses?

(3) If such RNA exists in human tumors, is it encapsulated in a particle possessing the density and size of the RNA tumor viruses?

(4) Does the RNA of human tumor particles possess homology to the RNA of the viruses causing the corresponding disease in animals?

(5) The virogene concept proposes that all animals prone to cancer carry in their germ line a complete copy of the information required to convert a cell from normal to malignant and for the production of tumor virus particles. Is this concept valid for randomly bred populations and in particular for the human disease?

\section{THE ANIMAL MODELS AS A POINT OF DEPARTURE}

To better understand the biological rationale underlying the experiments to be described, it is useful to summarize briefly some of the salient features of the animal model systems used as a guide. Table 2 lists a representative 
Table 2. Comparison of some representative oncornaviruses

\begin{tabular}{|c|c|c|c|c|c|c|c|}
\hline \multirow[t]{2}{*}{ Virus } & \multirow[t]{2}{*}{$\begin{array}{l}\text { Indigenous } \\
\text { Host }\end{array}$} & \multicolumn{5}{|c|}{ Homology* } & \multirow[t]{2}{*}{ Disease } \\
\hline & & AMV & RSV & MuLV & MSV & MMTV & \\
\hline AMV & Chicken & + & + & - & - & - & Leukemia \\
\hline RSV(RAV) & Chicken & + & + & - & - & - & Sarcoma \\
\hline MuLV & Mouse & - & - & + & + & - & $\begin{array}{l}\text { Leukemia, } \\
\text { Lymphoma }\end{array}$ \\
\hline MSV(MuLV) & Mouse & - & - & + & + & - & Sarcoma \\
\hline MMTV & Mouse & - & - & - & - & + & Breast Cancer \\
\hline
\end{tabular}

\begin{abstract}
*The results of molecular hybridizations between $\left.{ }^{3} \mathrm{H}\right] \mathrm{DNA}$ complementary to the various RNAs and the indicated RNAs. The plus sign indicates the hybridizations were positive and the negative sign indicates none could be detected.
\end{abstract}

group of animal viruses, including those actually employed to generate the molecular probes used. There are two avian viruses, myeloblastosis virus (AMV) and Rous sarcoma virus (RSV), that cause leukemias and sarcomas in chickens. In addition, we have the murine leukemia virus (MuLV) and murine sarcoma virus (MuSV) that induce similar diseases in mice, and finally the murine mammary tumor virus (MMTV), which is the unique etiologic agent for mammary tumors.

When these are examined for sequence homologies amongst their nucleic acids, a rather informative pattern emerges. It will be noted that the two chicken agents (AMV and RSV) have sequences in common but do not show detectable homology with any of the murine agents. Turning to the murine viruses, we find that the nucleic acids of the leukemia, lymphoma, and sarcoma agents show homology to one another but not to either of the two avian agents or to the mammary tumor virus. Finally, the mouse mammary tumor virus has a singular sequence homologous only to itself.

It is important to understand that a plus sign does not indicate identity but simply sufficient similarity to be detectable by the relaxed hybridization conditions used in these initial exploratory experiments. Similarly, a negative sign does not imply a complete absence of sequence homology but rather that none was detectable by the procedures employed.

If analogous virus particles are associated with the corresponding human diseases, certain predictions might be hazarded on the basis of the specificity patterns exhibited in Table 2, and these may be listed as follows:

(1) In view of the lack of homology between the avian and murine agents, it is unlikely that human agents, should they exist, would show homology to the avian group.

(2) It follows that the murine tumor viruses would represent a more hopeful source of the molecular probes to search for similar information in the analogous human cancers.

(3) If particles are found to be associated with human leukemias, sarcomas, and lymphomas, their RNAs might show homology to one another and possibly to that of the murine leukemia virus.

(4) If RNA particles are identified in human breast cancer, these should not exhibit homology to the RNA of the virus-like particles associated with the human lymphoid neoplasias or to RLV RNA but might exhibit some homology to the RNA of the murine mammary tumor virus.

On the basis of availability and the considerations outlined above, it is clear why the murine agents were initially chosen for producing the necessary molecular probes to look for corresponding information in the human disease. Furthermore, the desire to monitor the biological consistency of our findings dictated that we examine in parallel the human neoplasias listed. This would permit us to quickly determine whether our findings in humans mirrored biologically what was known from the animal experimental models. For this purpose, from the onset, we focused our efforts on the lymphoid neoplasias and on breast cancer.

\section{MOLECULAR HYBRIDIZATION WITH RADIOACTIVE DNA PROBES}

To answer the first question posed on whether human tumors contain viral-related RNA's, we naturally turned to the use of DNA-RNA hybridization, ${ }^{38}$ which we designed some dozen years ago to answer questions of almost precisely this nature in the case of virus-infected bacteria. The method depends on the ability of any piece of single-stranded DNA to find its complementary RNA and form, under the proper conditions, a double-stranded hybrid structure. The reaction is highly specific and has proved to be of considerable value in molecular biology over the past decade.

The radioactive DNA needed was synthesized by supplying detergent-disrupted virus preparations with magnesium and the four deoxyribosidetriphosphates required, one of them being labeled with tritium. When the synthesis is terminated, the protein and the RNA present are eliminated and the residual radioactive DNA purified to completion. Each $\left[{ }^{3} \mathrm{H}\right] \mathrm{DNA}$ preparation must be rigorously monitored for the specificity of its hybridizability to its appropriate template. Thus, each probe is challenged with its homologous RNA as well as with the other unrelated viral RNA's. Further, normal and cancer tissue RNA's from animal models were used to check the reliability of the hybridizations. Only if a probe demonstrated the required specificity in these test hybridizations was it used for the subsequent experiments with human material.

There are certain features built into these exploratory experiments that are worthy of explicit mention. We of course did not know at the outset whether there would be any homology between the murine viruses and any putative human agents. At the time RLV and MMTV were among the few mammalian oncornaviruses available in adequate supply and we could only hope that they would have sufficient homology to be used for our purpose. 
However, even if this hope were realized, it would hardly be likely that the homology would be extensive and therefore hybridization experiments had to be carried out under conditions sufficiently relaxed to yield a reaction with a limited level of homology. Further, the method of detection of hybrid structures would have to possess a low background noise level so that weak positive reactions would be readily identified and distinguished from negative outcomes. Finally, the $C_{r 0} t$ (concentration of nucleotides in $\mathrm{mol} / \mathrm{l} \times$ time in $\mathrm{sec}$ ) values of the annealing reactions were deliberately adjusted to be adequate for multiple (10 or more) rather than individual copies per cell. This was done in order to magnify any existent difference between normal and malignant tissue. We were not initially concerned with determining whether normal cells could produce the same or related malignant messages at very low levels.

All of these considerations entered into the design of the detailed methodology used and are diagrammed in Fig. 1. After monitoring for specificity, the purified viralspecific $\left[{ }^{3} \mathrm{H}\right] \mathrm{DNA}$ is mixed with cytoplasmic RNA prepared from a variety of human tumors and annealed under the conditions indicated. The hybridizations were always carried out with a vast excess of tumor RNA. Since the viral-specific $\left.{ }^{3} \mathrm{H}\right] \mathrm{DNA}$ is small compared with the RNA, any complexes formed between them will behave physically more like RNA than like DNA. Such complexes are readily detected by isopycnic separation in equilibrium density gradients of $\mathrm{Cs}_{2} \mathrm{SO}_{4}$. At the end of the centrifugation, the distribution of $\left[{ }^{3} \mathrm{H}\right] \mathrm{DNA}$ is examined across the gradient. Any uncomplexed DNA will remain at a density corresponding to about 1.45. DNA molecules that have annealed partially or completely to large RNA molecules will band at or near the density of RNA $(\rho=1 \cdot 65)$.

The movement of the $\left[{ }^{3} \mathrm{H}\right] \mathrm{DNA}$ to the RNA region is then the signal that the probe used has found complementary sequences in the tumor RNA with which it is being challenged. It is important to emphasize that this test is essentially a qualitative one and does not measure how good the fit is in the duplex. A positive outcome says only that sufficient homology exists between the tritiated DNA probe and some RNA molecules in the tumor RNA sample to form a complex stable enough to be detected by

Molecular hybridization of tumor p-RNA and viral specific ${ }^{3} \mathrm{H}$-DNA

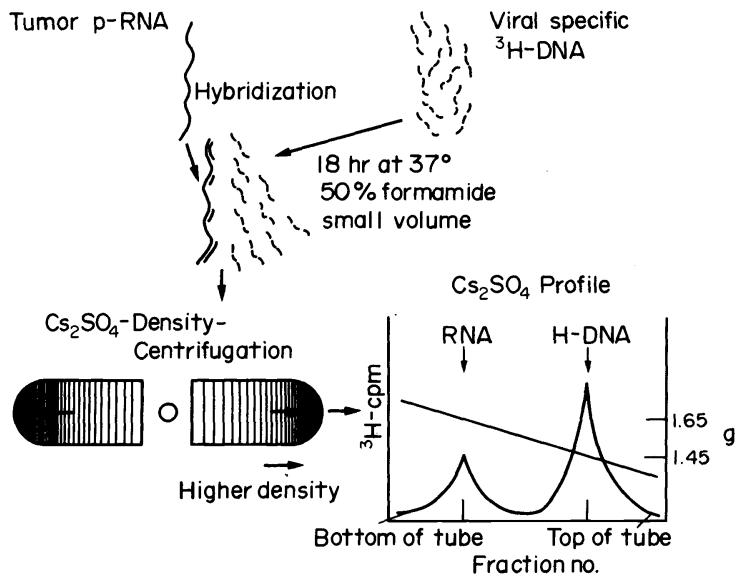

Fig. 1. Molecular hybridization and detection with viral-specific $\left[{ }^{3} \mathrm{H}\right] \mathrm{DNA}$ and tumor RNA (see text for further details). the test used. Once such structures are identified, the fidelity of the pairing can be examined by a temperaturemelt analysis. These more sophisticated examinations demand more hybrids than we could initially produce. It was therefore necessary to postpone these more informative experiments until more efficient probes became available.

We understandably began by exploring those human malignancies for which there were suitable animal models and viruses. These included adenocarcinoma of the breast,$^{2,3,34}$ the leukemias, ${ }^{18}$ the sarcomas ${ }^{23}$ and lymphomas. ${ }^{19}$ The leukemias examined encompassed both acute and chronic varieties of the lymphatic and myelogenous types. The human sarcomas studied included fibro, osteogenic, and liposarcomas. The series on lymphomas contained Hodgkin's disease, Burkitt's tumors, lymphosarcomas, and reticulum cell sarcomas. Control adult and fetal tissues were always examined in parallel and these were invariably negative. In the case of breast cancer, the two benign diseases, fibroadenoma and fibrocystic disease, were also included and found to be negative.

Table 3 summarizes in diagrammatic form the outcome of this survey of human neoplasias with the animal virus probes. The plus signs indicate that the corresponding [ $\left.{ }^{3} \mathrm{H}\right] \mathrm{DNA}$ formed complexes with the indicated tumor RNAs and the negative signs that no such complexes were detected. The proportion of positives amongst those labeled plus in these earlier studies ${ }^{2,3,18,99,23,34}$ ranged from about $67 \%$ for breast cancer to $92 \%$ for the leukemias. As our technology improved, so has our per cent positive amongst the neoplastic samples.

What is most noteworthy of the pattern exhibited in Table 3 is its concordance with the predictions deducible from the murine system. Thus, human breast cancer contains RNA homologous only to that of the murine mammary tumor virus (MMTV). Human leukemias, sarcomas, and lymphomas all contain RNA showing sufficient homology to that of the murine leukemia virus (RLV) to make a stable duplex. These lymphoid neoplasias contain no RNA homologous to the MMTV RNA. Finally, none of the human tumors contains RNA detectably related to that of the avian myeloblastosis virus (AMV). Recently Gallo and his associates ${ }^{11}$ have confirmed the homology of leukemic RNA to that of RLV and in the process have shown even more relatedness to the

Table 3. Homologies among human neoplastic RNAs and animal tumor viral RNAs

Human Neoplastic RNAs

\begin{tabular}{llcl}
\hline Biral RNAs & $\begin{array}{l}\text { Breast } \\
\text { Cancer }\end{array}$ & Leukemia Sarcoma Lymphoma \\
\hline
\end{tabular}

\begin{tabular}{|c|c|c|c|c|}
\hline MMTV & + & $\cdot \quad-$ & - & - \\
\hline RLV & - & + & + & + \\
\hline AMV & - & - & - & - \\
\hline
\end{tabular}

The results of molecular hybridization between $\left[{ }^{3} \mathrm{H}\right] \mathrm{DNA}$ complementary to the various viral RNA's and pRNA preparations from the indicated neoplastic tissues. The plus sign indicates that hybridizations were positive and the negative sign, that none could be detected. ${ }^{18}$ 
RNA of a simian sarcoma virus. In summary, the specificity pattern of the unique RNA found in the human neoplasias is in complete agreement with what has been described for the corresponding viral-induced malignancies in the mouse.

Needless to say, the existence of this remarkable concordance does not establish a viral etiology for these diseases in man. The next step requires performance of experiments designed to answer the second and third questions raised in the introduction, i.e. those relating to the size of the RNA being detected and whether it is associated with a reverse transcriptase in a particle possessing other features of complete or incomplete virus particles. We now turn our attention to the description of these techniques and their application to the analysis of human malignant tissue.

\section{SIMULTANEOUS DETECTION TEST FOR REVERSE TRANSCRIPTASE AND HIGH MOLECULAR WEIGHT RNA}

What we sought was a method of detecting the presence of particles similar to the RNA tumor viruses in human material that would be simple, sensitive, and sufficiently discriminating so that a positive outcome could be taken as an acceptable signal for the presence of a virus-like agent. To achieve this goal, we devised a test that depended on the simultaneous detection of two diagnostic features of the animal RNA tumor viruses.

The oncornaviruses exhibit two identifying characteristics. They contain a large $\left(1 \times 10^{7}\right.$ daltons in molecular weight) single-stranded RNA molecule having a sedimentation coefficient of $60-70 \mathrm{~S}$, often referred to as high molecular weight (HMW) RNA. They also have reverse transcriptase $(4,42)$, an enzyme that can use the viral RNA as a template to make a complementary DNA copy. ${ }^{37}$

The possibility of a concomitant test for both the enzyme and its template was suggested by our prior experience with RNA transcriptase. We found ${ }^{38}$ that the growing RNA chain could be detected as a complex with its DNA template. Similarly, examination of the early reaction intermediate ${ }^{31,37}$ of the reverse transcriptase reaction revealed that the initial DNA product was found complexed to the large 70S RNA template. These structures can be detected by the unusual position of the newly synthesized small tritiated DNA products in $\mathrm{Cs}_{2} \mathrm{SO}_{4}$ density gradients, glycerol velocity gradients, and acrylamide gel electrophoresis. ${ }^{8}$ The most informative assay is to subject the isotopically labeled product to sedimentation analysis prior to the removal of the RNA. If the labeled DNA product behaves as if it is a $70 \mathrm{~S}$ molecule, and if it can be shown that it does so because it is complexed to a 70S RNA molecule, then evidence is provided for the presence of a reverse transcriptase using a 70S RNA template. One may then tentatively conclude that the material examined contains particles similar to the RNA tumor viruses.

It was on this basis that Schlom and Spiegelman ${ }^{33}$ developed the simultaneous detection test, which was used to demonstrate ${ }^{35}$ the presence in human milk of particles containing 70S RNA and a reverse transcriptase. The text was modified ${ }^{16}$ to be applicable to tumor tissue using the mouse mammary tumor as the experimental model.

Figure 2 diagrams the procedure used. Tumor cells are first broken by the use of a Dounce homogenizer and the nuclei and large cell debris removed by low speed centrifugation. The supernate is subjected to trypsin digestion to inactivate any nucleolytic enzymes and the trypsin neutralized by trypsin inhibitor. The supernate is then centrifuged at a $150,000-\mathrm{g}$ to yield a cytoplasmic pellet containing virus particles, if present. The resulting pellet is then banded isopycnically in a sucrose density gradient and the fraction between $1 \cdot 16$ and $1 \cdot 19 \mathrm{~g} / \mathrm{ml}$ collected and concentrated by centrifugation. This pellet is then treated with a nonionic detergent $(0 \cdot 1 \%$ of NP-40) to disrupt possible viral particles and used in an endogenous reverse transcriptase reaction. It should be noted that detergent disruption is essential for a positive

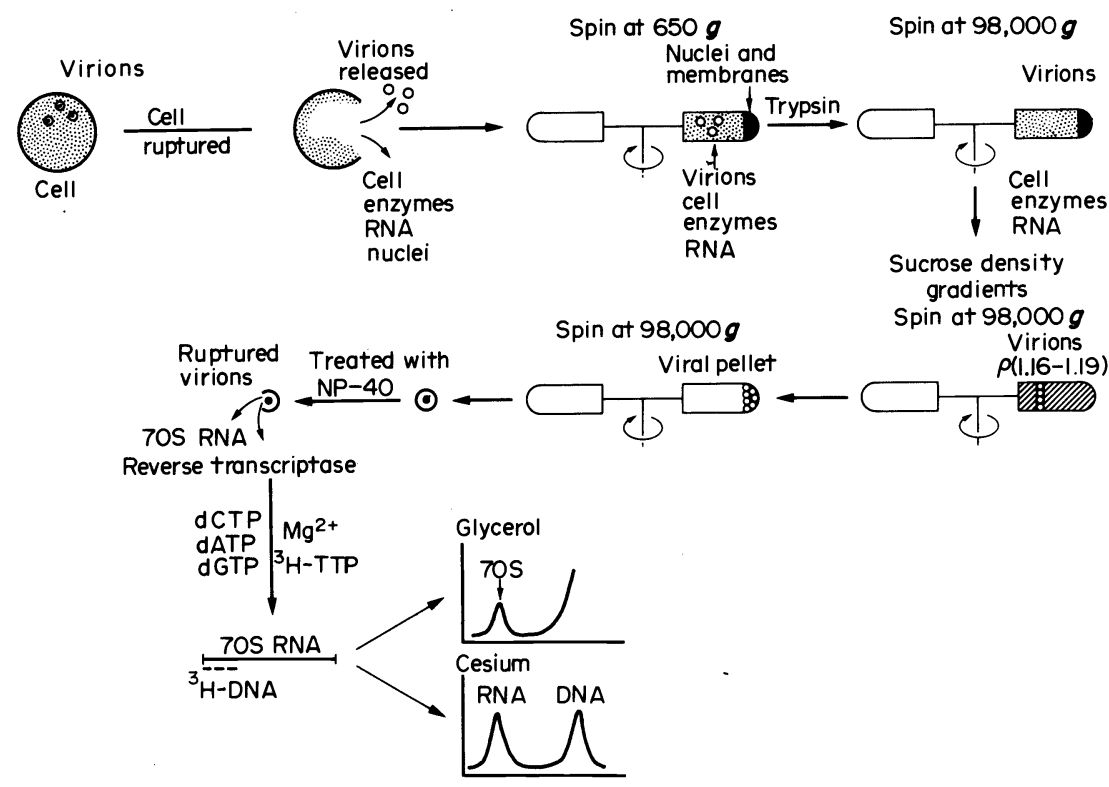

Fig. 2. Simultaneous detection test for 70S RNA and reverse transcriptase in neoplastic tissue (see text for further details). 
reaction, indicating that the enzyme and template are enclosed in a structure that must be opened up to make them accessible to the substrates. Actinomycin D is always included (100-200 $\mu \mathrm{g} / \mathrm{ml})$ to inhibit DNA-instructed DNA synthesis. The product of the reaction with its RNA template is freed of protein and then analyzed in a glycerol velocity gradient to determine the sedimentation coefficient of the $\left[{ }^{3} \mathrm{H}\right] \mathrm{DNA}$ as well as in a $\mathrm{Cs}_{2} \mathrm{SO}_{4}$ equilibrium gradient to determine its density.

The presence of particles encapsulating 70S RNA and reverse transcriptase will be indicated by the appearance of a peak of newly synthesized DNA traveling at a speed corresponding to a 70S RNA molecule. That its apparent large size is due to its being complexed to a 70S RNA molecule can be readily verified by subjecting the purified nucleic acid to ribonuclease prior to velocity examination and this should result in the disappearance of the "70S" $\left[{ }^{3} \mathrm{H}\right]$ DNA. Similarly, if the reaction is positive, newly synthesized DNA should appear in the RNA and hybrid regions of a $\mathrm{Cs}_{2} \mathrm{SO}_{4}$ density gradient, and this again should be eliminated by prior treatment with ribonuclease.

The simultaneous detection test was first applied to human breast cancer ${ }^{1}$ and Fig. 3 exemplifies a positive reaction with material obtained from a malignant adenocarcinoma and treated as outlined in Fig. 2. Here we see the 70S DNA complex observed with the P-100 fraction and it is evident that this complex is an RNA-dependent one since prior treatment with ribonuclease eliminates the $\left[{ }^{3} \mathrm{H}\right] \mathrm{DNA}$ from the $70 \mathrm{~S}$ region of the velocity gradient. In this series, 38 adenocarcinomas and ten nonmalignant controls were examined in this manner. It was found that $79 \%$ of the malignant samples were positive for the simultaneous detection reaction and all of the control samples from normal and benign tissue were negative.

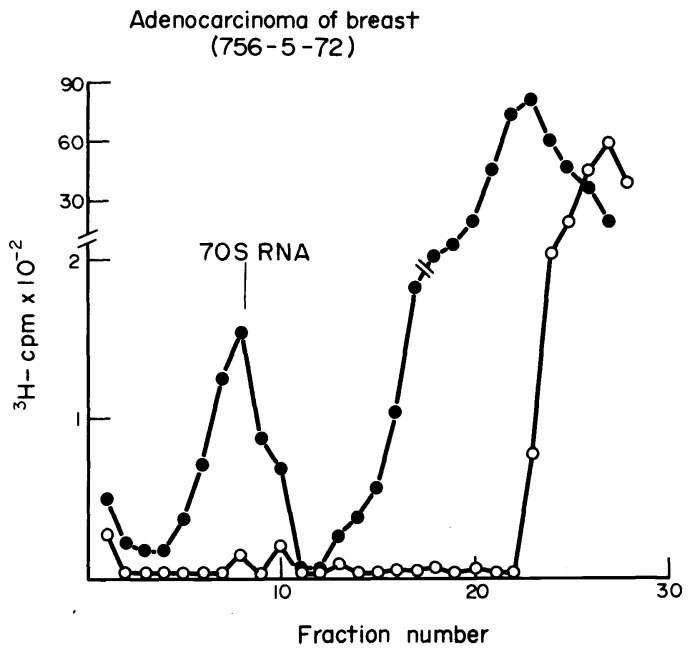

Fig. 3. Effect of ribonuclease on the detection of the highmolecular-weight RNA- $\left[{ }^{3} \mathrm{H}\right] \mathrm{DNA}$ complex. Breast tumor tissue (adenocarcinoma 756-5-72) was processed as described in Fig. 2. The viral pellet (P-100) was suspended in $0.01 \mathrm{M}$ Tris- $\mathrm{HCl}(\mathrm{pH} 8 \cdot 3)$ and divided into two equal parts. A standard RNA-instructed DNA polymerase reaction was performed on one part of the P-100 fraction; after incubation for $15 \mathrm{~min}$ at $37^{\circ}$, the nucleic acid complex was extracted with phenol-cresol and was sized on a 30-10\% linear glycerol gradient (---O). After disruption with detergent, the other half of the P-100 fraction was incubated in the presence of RNase A $(50 \mu \mathrm{g} / \mathrm{ml})$ and RNase $T_{1}(50 \mu \mathrm{g} / \mathrm{ml})$ for $15 \mathrm{~min}$ at $25^{\circ}$. A standard RNA-instructed DNA polymerase reaction was then performed $\left(\mathrm{O}_{---O}\right)^{1}$
The data obtained therefore indicated that one can, with a high probability, find in human breast cancers particulate elements that encapsulate RNA-instructed DNA polymerase and a 70S RNA. It was of obvious interest to see whether this reaction peaked in the density region characteristic of an RNA tumor virus. To this end, aliquots of pellet fractions, which gave positive simultaneous detection tests, were first subjected to sucrose equilibrium centrifugation in a linear gradient of $25-50 \%$ sucrose. The gradient was then divided into 10 equal fractions, which were diluted to $15 \%$ sucrose and spun at $100,000 \mathrm{~g}$ for $1 \mathrm{hr}$ to pellet any particles present. Each of these pellets was then tested to determine the distribution in the density gradient of the reaction that yields a $70 \mathrm{~S}$ RNA-instructed DNA-synthesizing activity. It is clear from the results shown in Fig. 4 that particles possessing the reverse transcriptase activity and its 70S RNA template localize at a density between 1.16 and $1.19 \mathrm{~g} / \mathrm{ml}$, the density characteristic of the oncogenic viruses.

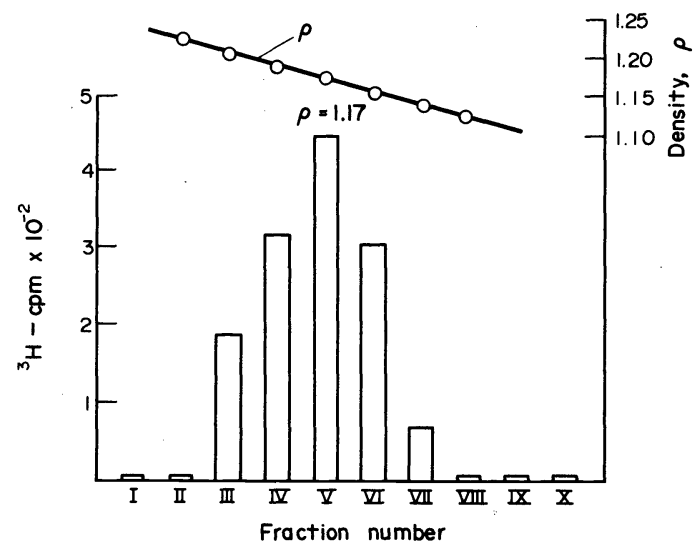

Fig. 4. Density of 70S RNA and RNA-instructed DNA polymerase activity in extracts of human mammary tumors by sucrose gradient centrifugation. A P-100 pellet was prepared from human mammary tumor. The pellet was suspended in Tris-NaCl-EDTA buffer and layered on a linear gradient of 50-25\% sucrose in the same buffer and spun at $25,000 \mathrm{rpm}$ in a SW27 (Spinco) rotor at $4^{\circ}$ for $195 \mathrm{~min}$. The gradient was dripped from below and ten equal fractions were collected; fractions were then diluted with Tris$\mathrm{NaCl}$-EDTA buffer to a sucrose concentration of less than $15 \%$. Each fraction was then spun at $100,000 \mathrm{~g}$. The amount of $70 \mathrm{~S}$ $\left[{ }^{3} \mathrm{H}\right] \mathrm{DNA}$ synthesized by an endogenous RNA-instructed DNA polymerase was determined by glycerol velocity centrifugation.

\section{APPLICATION OF THE SIMULTANEOUS DETECTION TEST TO THE LEUKEMIAS}

In the study of the leukemias, ${ }^{5}$ peripheral leukocytes were prepared from the buffy coats of both leukemic and nonleukemic control patients. Cells were disrupted and fractionated as described in Fig. 2. Representative experiments examining the effects of ribonuclease treatment of the product and omission of one of the deoxytriphosphates during the reaction are shown in Fig. 5. We see the telltale 70S peaks of DNA synthesized by the pellet fractions from the leukocytes of patients with acute lymphoblastic and acute myelogenous leukemias. The elimination of the complex by prior treatment with ribonuclease (Fig. 5A) shows that the tritiated DNA is indeed complexed to a 70S RNA molecule. Further, the omission of dATP (Fig. 5B) leads to a failure to form the $70 \mathrm{~S}$ complex, a result expected if the reaction is in fact leading to the synthesis of a proper heteropolymer. In 

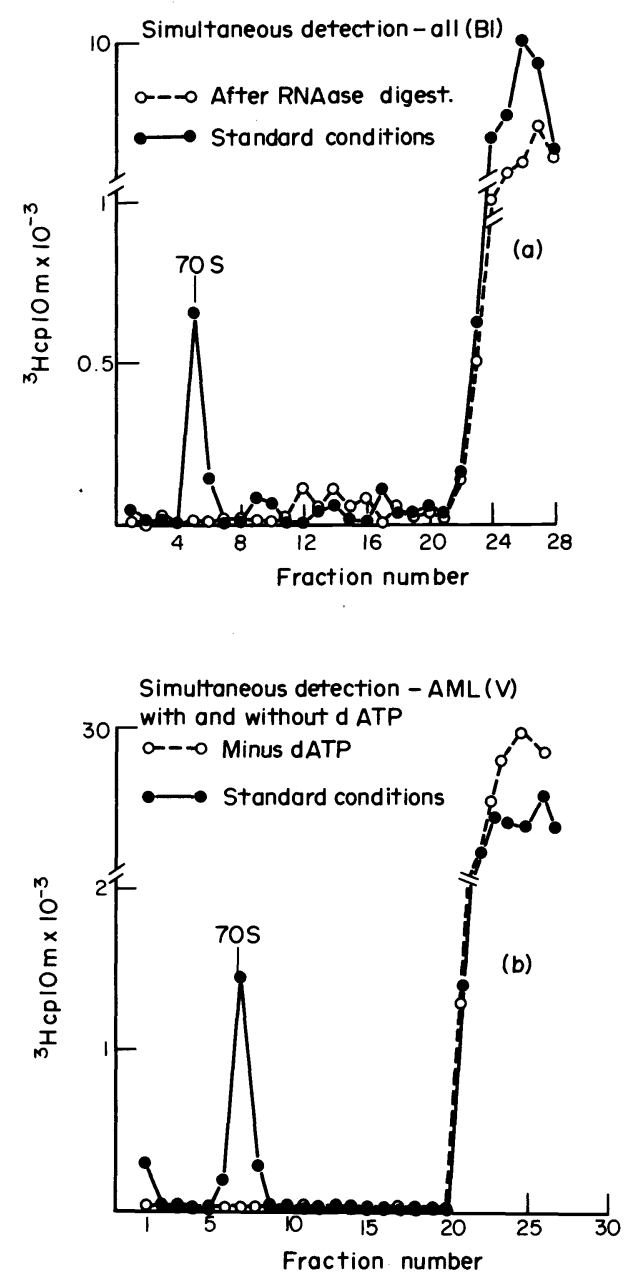

Fig. 5. Detection of $70 \mathrm{~S}$ RNA[ $\left.{ }^{3} \mathrm{H}\right] \mathrm{DNA}$ complex in human leukemic cells. One gram of leukemic WBC was washed in $5 \mathrm{ml}$ of $0.01 \mathrm{M} \mathrm{NaCl}, 0.01 \mathrm{M}$ Tris- $\mathrm{HCl}, \mathrm{pH} \mathrm{7.4}$, resuspended in $4 \mathrm{ml}$ of $5 \%$ sucrose, $0.005 \mathrm{M}$ EDTA, $0.01 \mathrm{M}$ Tris- $\mathrm{HCl}, \mathrm{pH} \mathrm{8.3}$, and ruptured with three strokes of a Dounce homogenizer. The nuclei were removed by low speed centrifugation $\left(2000 \mathrm{~g}, 5 \mathrm{~min}, 2^{\circ} \mathrm{C}\right)$. The supernatant was brought to a final concentration of $1 \mathrm{mg} / \mathrm{ml}$ trypsin (Worthington) and incubated at $37^{\circ} \mathrm{C}$ for $30 \mathrm{~min}$. A ten-fold excess of lima bean trypsin inhibtor (Worthington) was added (final concentration $3 \mathrm{mg} / \mathrm{ml}$ ) and the solution again centrifuged at $2000 \mathrm{~g}$ for $5 \mathrm{~min}$ at $2^{\circ} \mathrm{C}$. The supernatant was then centrifuged at $45,000 \mathrm{rpm}$ for $60 \mathrm{~min}$ at $2^{\circ} \mathrm{C}$. The resulting cytoplasmic pellet was resuspended in $0.5 \mathrm{ml}$ of $0.01 \mathrm{M}$ Tris- $\mathrm{HCl}, \mathrm{pH} 8.3$, brought to $0.1 \%$ Nonidet P-40 (Shell Chemical Co.) and incubated at $0^{\circ} \mathrm{C}$ for $15 \mathrm{~min}$. DNA was synthesized in a typical reverse transcriptase reaction mixture (final vol $1 \mathrm{ml}$ ) containing: $50 \mu \mathrm{mol}$ of Tris- $\mathrm{HCl}$, pH 8.3, $20 \mu \mathrm{mol} \mathrm{NaCl}, 6 \mu \mathrm{mol} \mathrm{MgCl}_{2}, 100 \mu$ mol each of dATP, dGTP, dCTP, and $50 \mu \mathrm{mol}-\left[{ }^{3} \mathrm{H}\right] \mathrm{dTTP}$ (Schwarz Biochemical, $800 \mathrm{cpm}$ per pmol). $50 \mu \mathrm{g} / \mathrm{ml}$ actinomycin $\mathrm{D}$ were added to inhibit DNA-instructed DNA synthesis. After incubation at $37^{\circ} \mathrm{C}$ for $15 \mathrm{~min}$, the reaction was adjusted to $0.2 \mathrm{M} \mathrm{NaCl}$ and $1 \%$ SDS, and deproteinized by phenol-cresol extraction. The aqueous phase was layered on a 10 to $30 \%$ gradient of glycerol in TNE buffer $(0.01 \mathrm{M}$, Tris- $\mathrm{HCl}, \mathrm{pH} 8.3,0.1 \mathrm{M}, \mathrm{NaCl}, 0.003 \mathrm{M}$, EDTA) and centrifuged in a SW-41 rotor Spinco at $40,000 \mathrm{rpm}$ for $180 \mathrm{~min}$ at $2^{\circ} \mathrm{C}$. Fractions were collected from below and assayed for TCA-precipitable radioactivity. In this, as in all sedimentation analysis, 70S RNA of the avian myeloblastosis virus was used as a marker.

(A) One aliquot of product was run on the gradient as a control and the other was pretreated with $20 \mu \mathrm{g}$ of RNase 1 (Worthington) for $15 \mathrm{~min}$ at $37^{\circ} \mathrm{C}$ prior to sedimentation analysis.

(B) Reactions with and without dATP. ${ }^{5}$ similar experiments, it was shown that omission of either dCTP or dGTP also resulted in the absence of the 70S RNA- $\left[{ }^{3} \mathrm{H}\right] \mathrm{DNA}$ complex, all of which argues against nontemplated end addition reactions.

In some cases leukemic cells were obtained in amounts adequate to permit a more complete characterization of the product. Hybridization of the human product to the appropriate viral RNA's provides the most revealing information since it tests sequence relatedness to known oncogenic agents. We summarize in Table 4 the results of examining the peripheral leukocytes of 23 patients, all in the active phases of their disease, including both acute and chronic leukemias. Of the 23 leukemic patients examined, 22 showed clear evidence that their peripheral leukocytes contained particles mediating a reaction leading to the appearance of endogenously synthesized DNA in the $70 \mathrm{~S}$ region of a glycerol gradient. Nine of these were tested for ribonuclease sensitivity and in all cases the complexes were destroyed. In nine others, the DNA was recovered from the complex and annealed to RLV RNA and to either MMTV RNA or AMV RNA. In all nine, hybridizations occurred with RLV RNA and not to either of the unrelated MMTV RNA or AMV RNA. In four patients, enough DNA complex was formed to permit a complete characterization of the product. In all four, the DNA complexes were destroyed by ribonuclease and the purified DNA hybridized uniquely to RLV RNA.

It is noteworthy that positive outcomes were observed in more than $95 \%$ of the leukemic patients whether they were acute or chronic, lymphoblastic or myelogenous. Thus, despite their disparate clinical pictures and differing cellular pathologies, these various types of leukemias have similar, though probably not identical, virus-related information.

In contrast with these results are those obtained with a control series of eighteen white blood samples from nonleukemic patients. These included nine with elevated white blood cell counts (in the range of $25,000 / \mathrm{mm}^{3}$ ) due to a variety of disorders, including polycythemia vera. None of these exhibited evidence of an RNA-DNA complex that was ribonuclease-sensitive and contained DNA that hybridized specifically with RLV RNA. Thus, none of the eighteen nonleukemic individuals exhibited evidence of the specific 70S RNA-directed DNA synthesis found in virtually all of the leukemic patients examined.

\section{IMPLICATIONS OF SIMULTANEOUS \\ DETECTION TESTS ON HUMAN BREAST CANCER AND THE LEUKEMIAS}

The experiments we have just summarized on human breast cancer and the leukemias were designed to probe further the etiological significance of our exploratory investigations, ${ }^{2,18}$ which identified in these neoplasias RNA homologous to those of the corresponding murine oncornaviruses. The data obtained with the simultaneous detection test established that at least a portion of the tumor-specific virus-related RNA we were detecting was a 70S RNA template physically associated with a reverse transcriptase in a particle possessing a density between $1 \cdot 16$ and $1 \cdot 19 \mathrm{~g} / \mathrm{ml}$, three of the diagnostic features of the animal RNA tumor viruses. Further, the DNA synthesized in the particles from both classes of neoplasias hybridized uniquely to the RNA of the corresponding oncornavirus. Note that this last result is complementary to and completes the logic of our experimental approach. We started out by using animal tumor viruses to generate 
Table 4. Simultaneous detection of 70S RNA and reverse transcriptase in leukemic cells ${ }^{5}$

\begin{tabular}{|c|c|c|c|c|}
\hline Leukemias & $\begin{array}{l}\text { Simultaneous } \\
\text { Detection } \\
\text { cpm }\end{array}$ & $\begin{array}{l}\text { RNase } \\
\text { Sensi- } \\
\text { tivity }\end{array}$ & $\begin{array}{c}\text { Hybridization } \\
\text { to RLV-RNA }\end{array}$ & $\begin{array}{l}\text { Hybridization } \\
\text { to AMV-RNA or } \\
\text { MMTV-RNA }\end{array}$ \\
\hline \multicolumn{5}{|c|}{ Acute Lymphatic } \\
\hline$O D$ & 400 & + & NT & NT \\
\hline Sm & 95 & + & NT & NT \\
\hline \multicolumn{5}{|c|}{$\begin{array}{l}\text { Acute Lymphatic/ } \\
\text { Lymphosarcoma }\end{array}$} \\
\hline H1 & 805 & + & + & - \\
\hline $\mathrm{Hz}$ & 200 & NT & + & - \\
\hline$B x$ & 185 & + & NT & NT \\
\hline St & 105 & + & NT & NT \\
\hline \multicolumn{5}{|c|}{ Acute Myelogenous } \\
\hline Ge & 170 & + & NT & NT \\
\hline De & 985 & + & + & - \\
\hline $\mathrm{Be}$ & 305 & + & NT & NT \\
\hline Vi & 1295 & + & + & - \\
\hline Sh & 1010 & NT & + & - \\
\hline $\mathrm{s}$ & 115 & NT & + & - \\
\hline $\mathrm{Du}$ & 415 & NT & + & - \\
\hline $\mathrm{He}$ & 400 & NT & + & - \\
\hline B1 & 605 & + & NT & NT \\
\hline Ga & 215 & + & + & - \\
\hline c & 285 & + & NT & NT \\
\hline $\mathrm{Pe}$ & 0 & NT & NT & NT \\
\hline $\mathrm{Ne}$ & 1400 & NT & + & - \\
\hline \multicolumn{5}{|c|}{ Chronic Lymphatic } \\
\hline $\mathrm{Ri}$ & 200 & + & NT & NT \\
\hline \multicolumn{5}{|c|}{ Chronic Myelogenous } \\
\hline Ec & 405 & NT & + & - \\
\hline Har & 390 & NT & + & - \\
\hline An & 600 & NT & + & - \\
\hline
\end{tabular}

NT $=$ Not tested.

$\left[{ }^{3} \mathrm{H}\right] \mathrm{DNA}$ probes that were used to find related RNA in human neoplastic tissue. We concluded by using analogous human particles to generate $\left.{ }^{3} \mathrm{H}\right] \mathrm{DNA}$ probes, which were then used to determine sequence relatedness to the RNA of the relevant oncornaviruses. None of the human probes hybridized to the avian viral RNA. The probe generated by the particles from human breast cancer was homologous only to the RNA of mouse mammary tumor virus, whereas the human leukemic probe was related in sequence only to RLV RNA, the murine leukemic agent. The biologically logical consistency of these results adds further weight to their relevance to the human disease.

\section{ON THE PROBLEM OF GERM-LINE}

TRANSMISSION OF VIRAL INFORMATION

We now come to grips with the virogene-oncogene concept ${ }^{43}$ which derives from animal experiments and argues that all animals prone to cancer contain in their germ line at least one complete copy of the information necessary and sufficient to convert a cell from normal to malignant and produce the corresponding tumor virus. This hypothesis presumes that the malignant segment usually remains silent and that its activation by intrinsic or extrinsic factors leads to the appearance of virus and the onset of cancer.

There are various ways of testing the validity of the virogene-oncogene hypothesis, but the pathways differ in the technical complexities entailed. One approach commonly used attempts to answer the question: Does every normal cell contain at least one complete copy of the required viral-related malignant information? The methodologies used included the techniques of genetics, chemical viral induction, and molecular hybridizations. However, for a variety of reasons, none of these gave, or could give, conclusive answers. Genetic experiments do not readily distinguish between susceptibility genes and actual viral information. Further, even if genetic data succeeded in identifying some structural viral genes, it would still be necessary to establish that all the viral genes are represented in the genome. Attempts to settle the question by demonstrating that every cell of an animal can be chemically induced to produce viruses have thus far, for obvious reasons, not been tried. The best that has been achieved along these lines is to show that cloned cells do respond positively. However, the proportion of clonable cells is small and clonability may well be a signal for prior infection with a tumor virus.

Finally, the quantitative limitations of molecular hybridization make it almost impossible to provide definitive proof that each cell contains one complete viral copy in its DNA. Although it is not very difficult to show that $90 \%$ of the information is present, it is the last $10 \%$ that constitutes the insurmountable barrier and $10 \%$ of $3 \times 10^{6}$ daltons amounts to a far from trivial $3 \times 10^{5}$ daltons, the equivalent of about one gene.

A useful way to obviate these technical difficulties is to invert the problem. Instead of asking whether one complete copy exists in normal cells, the question can be phrased in the following terms: Does the DNA of a malignant cell contain viral-related sequences that are not found in the DNA of its normal counterpart? Phrasing the issue in this manner leads to the design of experiments that avoid the uncertainties generated by the demonstrated fact that many indigenous RNA tumor viruses 
share, completely or partially, some sequences with the normal DNA of their natural hosts. ${ }^{32}$ The crucial point is of course whether all of the viral sequences are to be found in normal DNA. The approach we adopted requires removal of those viral sequences that are contained in non-neoplastic DNA by exhaustive hybridization of the viral probe to normal DNA in vast excess. Any unhybridized residue can then be used to determine whether malignant DNA contains viral-related sequences not detectable in normal tissue.

We first investigated this question in the case of the human leukemias ${ }^{6}$ and the strategy, as diagrammed in Fig. $6(\mathrm{a}, \mathrm{b})$, may be outlined in the following steps:

(a) Isolate from leukemic cells the fraction enriched for the particles encapsulating the 70S RNA and RNAdirected DNA polymerase;

(b) Use this fraction to generate $\left[{ }^{3} \mathrm{H}\right] \mathrm{DNA}$ endogenously synthesized in the presence of high concentrations of actinomycin D to inhibit host and viral DNA-directed DNA synthesis;

(c) Purify the $\left[{ }^{3} \mathrm{H}\right] \mathrm{DNA}$ by hydroxyapatite and Sephadex chromatography with care being exercised to remove by self-annealing and column chromatography all self-complementary material in the tritiated probe;

(d) Use the resultant $\left.{ }^{3} \mathrm{H}\right] \mathrm{DNA}$ to detect complementary sequences in normal and leukemic leukocyte DNA;

(e) If viral-related sequences are detected in both, remove those found in normal leukocytes by exhaustive hybridization to normal DNA; and

(f) Test the residue for specific hybridizability to leukemic DNA.

In carrying out the recycling and test hydridizations, it is imperative that conditions be chosen to account for the possibility that the leukemia-specific sequences are present in only one copy per genome, a possibility which is in fact realized. ${ }^{6}$ To this purpose, the concentration in moles per liter $\left(C_{0}\right)$ of DNA and the time $(t$ in sec) of annealing is adjusted to $C_{0} t$ values of 10,000 , which are adequate to locate unique sequences.

A typical outcome of hybridizing such recycled tritiated DNA to normal and leukemic DNA is shown in Fig. 7. It is

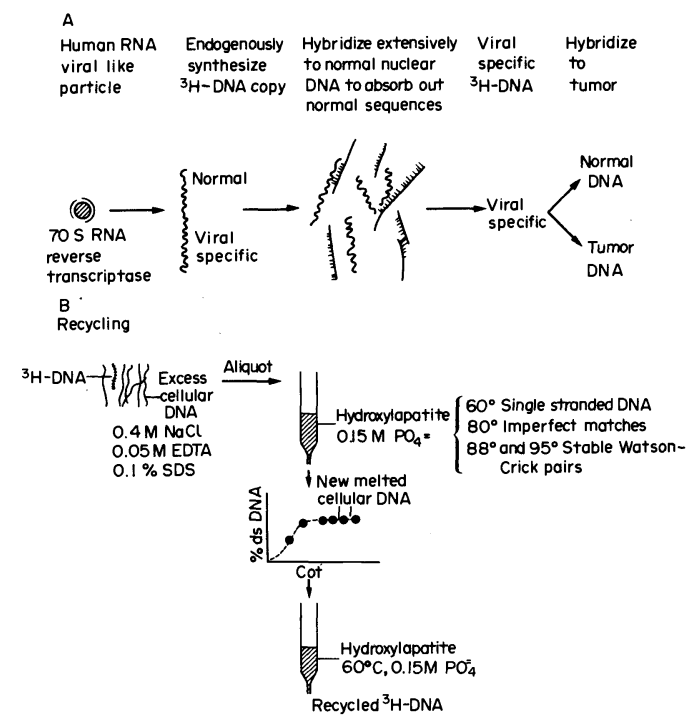

Fig. 6. (A) Generation of $\left[{ }^{3} \mathrm{H}\right] \mathrm{DNA}$ by human leukemic particles and hybridization of sequences shared with normal DNA.

(B) Separation of leukemia-specific sequences by hydroxyapatite chromatography. (See text for further details). evident that no complexes stable at temperatures above $88^{\circ} \mathrm{C}$ are formed with normal DNA. On the other hand, $57 \%$ of the recycled $\left.{ }^{3} \mathrm{H}\right] \mathrm{DNA}$ probe forms well-paired duplexes with leukemic DNA. A series of such experiments was performed with particle-generated $\left.{ }^{3} \mathrm{H}\right] \mathrm{DNA}$ and nuclear DNA obtained from 8 untreated patients with either acute or chronic myelogenous leukemia. In every case (Table 5), the $\left[{ }^{3} \mathrm{H}\right] \mathrm{DNA}$, after being subjected to exhaustive annealing to normal DNA, yielded a residue that forms stable duplexes only with leukemic DNA, in agreement with the experiment in Fig. 7.

In estimating the implication of this result, it must be recalled that the leukemia-specific sequences found ${ }^{6}$ in leukemic cells are present as nonreiterated copies per genome. This was established by the $C_{0} t$ values (concentration of nucleotides $\times$ time) required to detect them. The sensitivity used to examine normal cells for the leukemia-specific sequences was such that $1 / 50$ th of an equivalent of that found in leukemic cells would have been readily detected. Consequently, one may conclude that the vast majority of normal cells do not contain this particular stretch of malignant information and it cannot therefore be represented in the germ line of nonleukemic individuals.

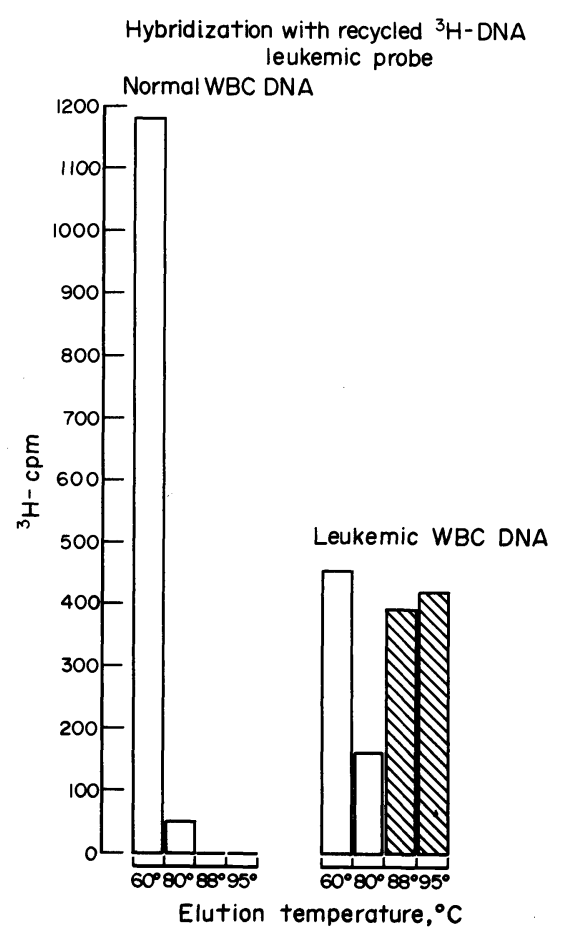

Fig. 7. Hydroxyapatite elution profile of a hybridization reaction of recycled leukemic $\left[{ }^{3} \mathrm{H}\right] \mathrm{DNA}$ to nuclear DNA from normal leukocytes and from leukemic leukocytes of the patient from which the $\left[{ }^{3} \mathrm{H}\right] \mathrm{DNA}$ was derived.

\section{UNIQUE SEQUENCES IN HODGKIN'S AND BURKITT'S LYMPHOMAS AND THEIR RELATEDNESS}

We have already noted that, like the leukemias, Hodgkin's and Burkitt's lymphomas have particles containing reverse transcriptase and a 70S RNA template related in sequence to that of RLV. It was of obvious interest to determine whether the lymphomas also parallel the leukemias in possessing a unique sequence not detectable in normal tissue. If they do, one can in addition ascertain whether the sequences found in Hodgkin's and 
Table 5. Exhaustive hybridization of $\left[{ }^{3} \mathrm{H}\right] \mathrm{DNA}$ probe synthesized by leukemic particles with normal-leukocyte nuclear DNA, followed by hybridization of the nonhybridizing recycled leukemic $\left[{ }^{3} \mathrm{H}\right] \mathrm{DNA}$ probe to normal DNA and to leukocyte nuclear DNA from the same leukemic patient ${ }^{6}$

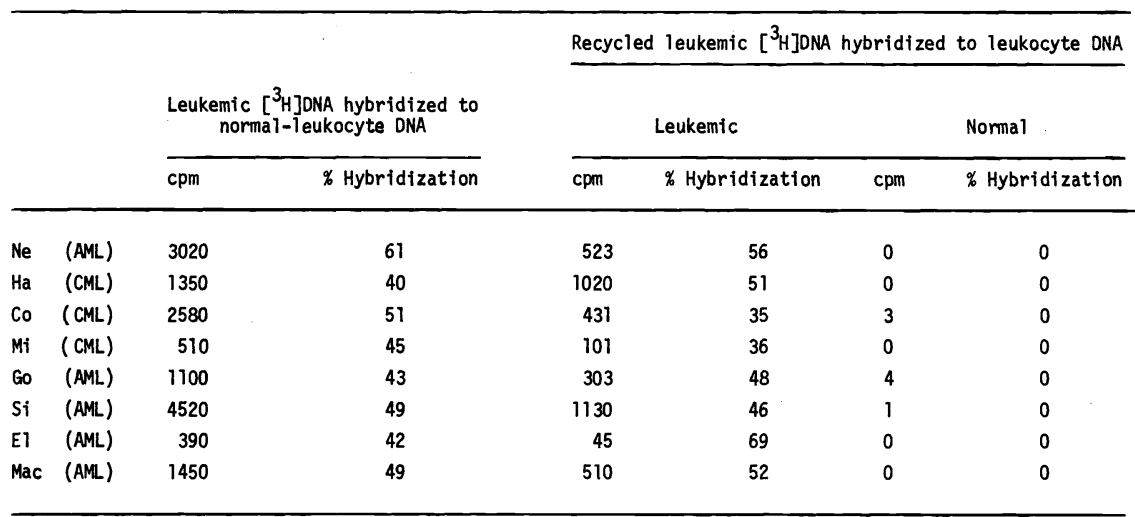

Background was $30 \mathrm{cpm}$ and all counts recorded represent $\mathrm{cpm}$ above background. $\mathrm{CML}=$ Chronic myelogenous leukemia. $\mathrm{AML}=$ Acute myelogenous leukemia. First column indicates initials of patients.

Burkitt's lymphomas are related to each other. The outcome has evident significance for the relevance of the sequence to malignancy.

$\left[{ }^{3} \mathrm{H}\right]$ DNA probes were synthesized with particles isolated from four Burkitt's tumors and three Hodgkin's disease specimens. Sequences shared with normal DNA (between 35 and $40 \%$ ) were then removed as described for the leukemias ${ }^{6}$ to yield the recycled $\left[{ }^{3} \mathrm{H}\right]$ DNA probes. ${ }^{26}$

Figure 8 shows the outcome of challenging recycled Hodgkin's disease [ ${ }^{3} \mathrm{H}$ ]DNA with nuclear DNA from normal spleen, Hodgkin's disease spleen, and from Burkitt's lymphoma. Few, if any, stable duplexes are formed with normal DNA. Note, however, that although the probe was made with Hodgkin's disease particles, the $\left[{ }^{3} \mathrm{H}\right] \mathrm{DNA}$ hybridized to Burkitt's lymphoma nuclear DNA virtually as well as it complexed to DNA from Hodgkin's spleen. The converse is also true, as may be seen from Table 6, which summarizes the results of our findings in the recycled $\left[{ }^{3} \mathrm{H}\right] \mathrm{DNA}$ challenged with nuclear DNA from normal and malignant tissues. ${ }^{26}$ Again, normal DNA is

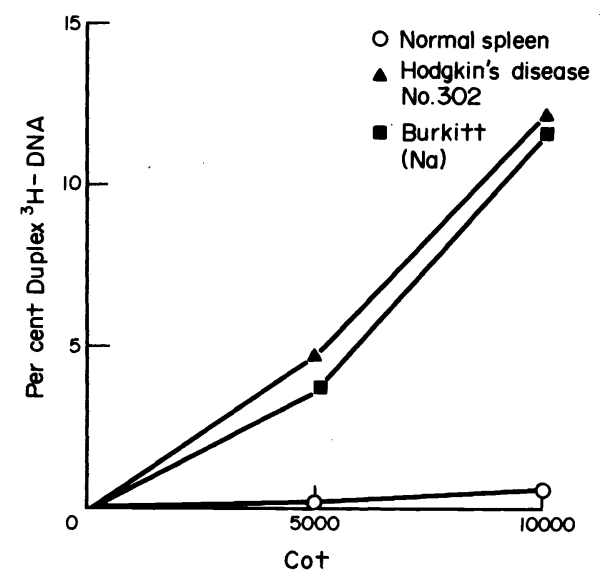

Fig. 8. Hybridization of recycled Hodgkin's disease \#302 $\left[{ }^{3} \mathrm{H}\right] \mathrm{DNA}$ to nuclear DNA isolated from normal spleen $(\mathrm{O}-\mathrm{-O})$, Hodgkin's disease No. $302(\boldsymbol{\Lambda}-\mathbf{\Delta})$, and Burkitt's lymphoma (Na) (-D). Equal aliquots were removed from the hybridization vessel at each $C_{0} t$ value and hybrid formation was analyzed by hydroxyapatite chromatography. The input counts for each point were $1500-2000 \mathrm{cpm}$ and only those duplexes eluting at $88^{\circ} \mathrm{C}$ and above are counted as stably hybridized. unable to form significant amounts of stable complexes (elution at $88^{\circ} \mathrm{C}$ and above) with the $\left[{ }^{3} \mathrm{H}\right] \mathrm{DNA}$ probes. In all instances, the lymphoma $\left[{ }^{3} \mathrm{H}\right] \mathrm{DNAs}$ hybridized in stable complexes to the nuclear DNA of the original types from which the particles were obtained and used to generate the labeled DNA. Further, with only one exception, all of the Burkitt's and Hodgkin's disease $\left[{ }^{3} \mathrm{H}\right] \mathrm{DNA}$ cross hybridize with each other's DNA.

In summary, several features emerged from this study of the lymphomas. The particle-related seuqences found in Burkitt's and Hodgkin's lymphomas possess sequences in common, an observation in accord with our earlier findings ${ }^{19,24,25,39}$ that Hodgkin's and Burkitt's particles both share sequences with the Rauscher murine leukemia agent. Further, in view of the previous association of the Epstein-Barr virus with Burkitt's lymphoma ${ }^{20,44}$ and the non-neoplastic infectious mononucleoses, ${ }^{21,30}$ it is revealing to note from Table 6 that the leukocyte DNA of patients with infectious mononucleosis was devoid of the Burkitt's sequences detected by the recycled $\left[{ }^{3} \mathrm{H}\right] \mathrm{DNA}$ probe, indicating that these latter sequences are specific for neoplastic tissues. The fact that the particle-related sequences in Hodgkin's and Burkitt's tumors are related to each other adds further weight to this conclusion. Finally, the observation that cells carrying multiple copies of the DNA of the Epstein-Barr virus do not complex with recycled [ $\left.{ }^{3} \mathrm{H}\right] \mathrm{DNA}$ probes from either Hodgkin's or Burkitt's particles proves that these particle sequences have no relation to the DNA of the Epstein-Barr virus.

\section{EVIDENCE FROM STUDIES OF IDENTICAL TWINS}

Although the comparison of leukemic patients with normals suggests that healthy individuals do not contain the leukemia-specific sequences, the data do not rule out the possibility that those who do come down with the disease do so because they in fact inherit the required information in their germ line. One way to resolve this issue is to study the situation in identical twins. Since identical twins are monozygous, i.e. derive their genomes from the same fertilized egg, any chromosomally transmitted information must be present in both. It had already been shown by Goh and his colleagues ${ }^{12,13}$ in the case of chronic myelogenous leukemia that only the leukemic member of each of two identical twin pairs contained the marker Philadelphia chromosome. It was of obvious 
Table 6. Hybridization of recycled $\left[{ }^{3} \mathrm{H}\right] \mathrm{DNA}$ probes synthesized with human lymphoma particles with nuclear DNA from normal and tumor tissues

\begin{tabular}{llcc}
\hline $\begin{array}{c}\text { Origin of }\left[{ }^{3} \mathrm{H}\right] \text { DNA } \\
\text { Recycled Probe }\end{array}$ & Nuclear DNA & $\begin{array}{c}\text { No. Tested } \\
\text { Positive Total }\end{array}$ & $\begin{array}{c}\text { Percent } \\
\text { Positives }\end{array}$ \\
\hline Burkitt's lymphomas & Burkitt's & $7 / 7$ & 100 \\
& Hodgkin's & $2 / 2$ & 100 \\
& Normal (spleen) & $0 / 4$ & 0 \\
& IM* (spleen) & $0 / 1$ & 0 \\
& IM* (cell) & $0 / 1$ & 0 \\
Hodgkin's disease & Hodgkin's & $3 / 3$ & 100 \\
& Burkitt's & $2 / 3$ & 67 \\
& Normal (spleen) & $0 / 3$ & 0 \\
\hline
\end{tabular}

*IM = infectious mononucleosis.

interest to examine this situation for the leukemia-specific sequences. If the leukemic member of the pair contains the particle-related DNA sequences, and does so because he inherited them through his germ line, then these same sequences must be found in the leukocyte DNA of his healthy sibling. To perform the experiment, it was necessary to locate identical twins with completely convincing evidence for monozygosity and where only one of them was leukemic. Further, the twins had to be of adult age since at least a unit of whole blood is required to provide enough leukocyte DNA to carry out the required hybridization.

Two sets of identical twins satisfying all these requirements were found and an experiment similar to the one outlined above was performed with each pair. ${ }^{7}$ In each instance, particles containing the reverse transcriptase and 70S RNA were again isolated from the leukocytes of the leukemic members and used to generate the $\left[{ }^{3} \mathrm{H}\right] \mathrm{DNA}$ endogenously. The $\left[{ }^{3} \mathrm{H}\right] \mathrm{DNA}$ was purified and sequences shared with normal DNA removed by exhaustive hybridization in the presence of a vast excess of normal DNA from random healthy blood donors. This was then followed by hydroxyapatite chromatography to separate paired from unpaired $\left[{ }^{3} \mathrm{H}\right] \mathrm{DNA}$. It is important to emphasize that in the recycling step, the normal DNA used came from the leukocytes of healthy, random blood donors and not from the normal twin. To have used the latter would have obviously confused the issue. The residue of the tritiated DNA that did not pair with the normal DNA was then used to test for the presence of a sequence in the leukocyte DNA of the patient and that of his healthy sibling.

The results obtained with the two sets of twins are described in Fig. 9 and it is evident that the same situation holds between the members of the twin pairs as was observed in the comparison of unrelated leukemic patients and random normals (Fig. 7 and Table 5). The leukemic twin contains particle-related sequences that cannot be detected in the leukocytes of his healthy sibling.

The fact that we could establish a sequence difference between identical twins implies that the additional information found in the DNA of the leukemic members was inserted after zygote formation. This finding argues against the applicability of the virogene hypothesis to this disease since it would demand that the leukemia-specific sequences found in the DNA of the individual with the disease must surely also exist in the genome of his
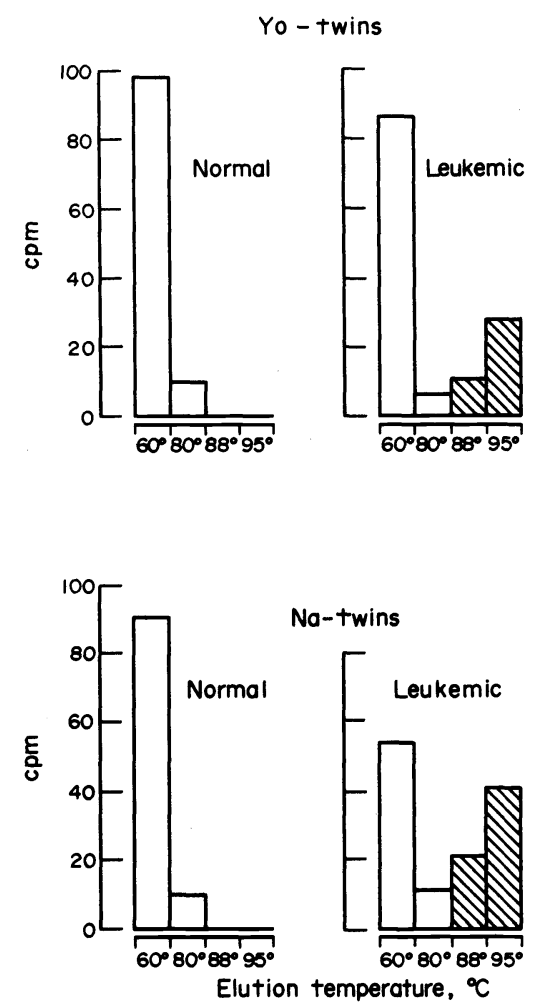

Fig. 9. Hydroxyapatite elution profile of a hybridization reaction of the recycled leukemic twin $\left[{ }^{3} \mathrm{H}\right] \mathrm{DNA}$ probe to nuclear DNA from normal leukocytes, normal twin leukocytes, and leukocytes from the leukemic twin.

The annealing reaction mixtures contained $20 \mathrm{~A}_{260}$ units of cellular DNA, $0.004 \mathrm{pmol}$ of $\left[{ }^{3} \mathrm{H}\right] \mathrm{DNA}$, and $15 \mu \mathrm{mol} \mathrm{NaH} \mathrm{PO}{ }_{4}(\mathrm{pH}$ 7.2 ) in a final vol of $0.01 \mathrm{ml}$. The reaction was brought to $98^{\circ} \mathrm{C}$ for $60 \mathrm{sec}$ and $0.04 \mathrm{mmol}$ of $\mathrm{NaCl}$ was added. The reaction mixture was then incubated at $60^{\circ} \times 50 \mathrm{hr}$. The reaction was stopped by the addition of $1 \mathrm{ml}$ of $0.05 \mathrm{M} \mathrm{NaH} \mathrm{PO}$ (pH 6.8). The sample was then passed over a column of hydroxyapatite of 20 -ml-bed vol at $60^{\circ} \mathrm{C}$ The column was washed with $40 \mathrm{ml}$ of $0.15 \mathrm{M} \mathrm{NaH} \mathrm{PO} 4(\mathrm{pH}$ 6.8) at $60^{\circ} \mathrm{C}, 80^{\circ} \mathrm{C}, 88^{\circ} \mathrm{C}$ and $95^{\circ} \mathrm{C}$. Fractions of $4 \mathrm{ml}$ were collected, the $\mathrm{A}_{260}$ of each fraction was read, and the DNA was precipitated with $2 \mu \mathrm{g} / \mathrm{ml}$ of carrier yeast RNA and $10 \%$ trichloroacetic acid. The precipitate was collected on Millipore filters, which were dried and counted. In all cases, greater than $80 \%$ of the nuclear DNA reannealed. A background count of $8 \mathrm{cpm}$ was subtracted in all instances. ${ }^{7}$ 
identical twin. These results are also inconsistent with the possibility that individuals who succumb to leukemia do so because they inherit the complete viral genome.

\section{PRESENT STATUS AND FUTURE PROSPECTS}

We have summarized here experiments indicating that human breast cancers and mesenchymal tumors contain particulate entities possessing several of the diagnostic features of the RNA tumor viruses. In addition to size and density, these include the presence of a 70S RNA molecule encapsulated in an internal core with an enzyme, reverse transcriptase, that can employ the RNA as a template to make a DNA copy. Further, the particulate RNA's of the leukemias, lymphomas and sarcomas are related in sequence to each other. The particulate RNA of human breast cancer possesses a unique sequence unrelated to those found in the mesenchymal tumors.

The fact that the human particles possess sequence homology to similar agents known to cause the corresponding neoplasias in mice encourages the hope that they are relevant to the human disease. However, despite the considerable progress that can be recorded, no definitive proof exists at the present writing that the virus-like particles found in the human neoplasias are either viruses or etiologic agents of the cancers in which they are found. Proof will ultimately come if it proves possible to produce the relevant malignancy in a susceptible animal by injection of particles purified from the human tumors. It should be noted, however, that we have known of the mouse mammary tumor virus for more than $35 \mathrm{yr}$ and no one has succeeded in producing mammary tumors with this agent in any animal, other than the mouse.

Under the circumstances, it would seem prudent not to wait for the definitive experiment with the human particles but rather to proceed with attempts at further exploration of their significance and possible clinical usefulness.

One important step forward would be accomplished by establishing particle-producing human tumor cells in short, or preferably, long-term culture. That this advance is in fact on its way is suggested by a number of recent reports. Thus, McGrath et al. ${ }^{29}$ describe a human breast carcinoma cell line that may be a source of breast cancer particles. Kotler et al. $^{22}$ have succeeded in inducing the release of virus-like particles from human leukemic cells by arginine starvation. Mak and his colleagues ${ }^{12,13}$ have been setting up short-term cultures of leukemic bone marrow aspirates in a conditioned medium and finding particles in the tissue culture fluid. Finally, and most recently, Gallagher and Gallo ${ }^{10}$ have reported what appears to be a highly productive line established from a patient with acute myelogenous leukemia. The particles produced appear to have some antigenic relatedness to the simian sarcoma agent. ${ }^{36}$

All attempts to establish productive long-term cultures are always exposed to the all pervasive danger of contamination with known animal oncornaviruses. Because of this, any evidence that the agent produced is either identical or even similar to a known animal oncornavirus has been accepted as sufficient evidence to condemn the culture and its particle as irrelevant to the human disease. It is important to recognize, however, that this is not a fool-proof argument. For example, it could well be true that a virus found initially in a non-human primate may have originally come from a human source. It is also not safe to conclude that an agent is human if it cannot be identified by either base sequence or antigenic properties with a known animal virus. Quite clearly, until our catalogue of all animal tumor viruses is complete, this line of reasoning has no compelling logical basis.

Is there at present any criterion that can be usefully used to decide whether a given tissue culture virus is in fact of possible relevance to human cancer? There is one possible answer to this question and it depends on the presence of unique viral-related sequences in the DNA of malignant cells. If the DNA of the original tumor from which the culture was derived contains sequences found in the particles produced by the tissue culture, then contamination during cultivation can be eliminated. If this condition is satisfied, the particle cannot be dismissed as an irrelevant contaminant no matter what its relatedness to known animal oncornaviruses.

There is one further comment that can be made about the presence of unique sequences in malignant DNA. Their existence is clearly not consistent with any mechanism that does not involve the insertion of viral-related sequences into the DNA of a malignant cell. Again this does not mean that other mechanisms are not operating, but these cannot, in the face of this evidence, be the sole mechanism. Further, the identical twin data require the postzygotic insertion into the genome of the viral information, a process known to occur with RNA tumor viruses in animal cells both in tissue culture ${ }^{14}$ and in whole animals ${ }^{40}$ under laboratory conditions.

It is evident that these findings suggest more optimistic pathways for the control of these diseases than would be available if the total information were already present in the genome. The data imply that in at least some cancers we may not be forced to master the control of our own genes in order to cope with these neoplasias. Finally, the existence of the leukemia-specific sequences can provide the clinician with a hitherto unsuspected parameter that could potentially be a useful adjunct in diagnosis and in monitoring therapy. Future efforts should attempt to extend these unique sequence differences to proteins for which they may well code. This would provide unique proteins as signals for the presence of the corresponding neoplasias and could open up the possibility of immunological approaches for both the diagnosis and the treatment of these diseases.

Acknowledgments-This study was supported by Grant CA-02332 and Contract No. N01-CP3-3258 within the Virus Cancer Program of the National Cancer Institute, National Institutes of Health.

\section{REFERENCES}

${ }^{1}$ R. Axel, S. C. Gulati and S. Spiegelman, Particles containing RNA-instructed DNA polymerase and virus-related RNA in human breast cancers. Proc. Nat. Acad. Sci. USA 69, 3133-3137 (1972).

${ }^{2}$ R. Axel, J. Schlom and S. Spiegelman, Presence in human breast cancer of RNA homologous to mouse mammary tumour virus RNA. Nature, New Biol. 235, 32-36 (1972).

${ }^{3}$ R. Axel, J. Schlom and S. Spiegelman, Evidence for translation of viral-specific RNA in cells of a mouse mammary carcinoma. Proc. Nat. Acad. Sci. USA 69, 535-538 (1972).

${ }^{4} \mathrm{D}$. Baltimore, RNA-dependent DNA polymerase in virions of RNA tumour viruses. Nature, New Biol. 226, 1209-1211 (1970). ${ }^{5}$ W. Baxt, R. Hehlmann and S. Spiegelman, Human leukemic cells contain reverse transcriptase associated with a high molecular weight virus-related RNA. Nature, New Biol. 240, 72-75 (1972).

${ }^{6}$ W. G. Baxt and S. Spiegelman, Nuclear DNA sequences present in human leukemic cells and absent in normal leukocytes. Proc. Nat. Acad. Sci. USA 69, 3737-3741 (1972).

${ }^{7}$ W. Baxt, J. W. Yates, H. J. Wallace Jr., J. F. Holland and S. 
Spiegelman, Leukemia-specific DNA sequences in leukocytes of the leukemic member of identical twins. Proc. Nat. Acad. Sci. USA 70, 2629-2632 (1973).

${ }^{8}$ D. H. L. Bishop, R. Ruprecht, R. W. Simpson and S. Spiegelman, Deoxyribonucleic acid polymerase of Rous sarcoma virus: Reaction conditions and analysis of the reaction product nucleic acids. J. Virol. 8, 730-741 (1971).

${ }^{9}$ A. M. Campbell, Episomes. p. 193, Harper \& Row, New York (1969).

${ }^{10}$ R. E. Gallagher and R. C. Gallo, Type-C RNA tumor virus isolated from cultured human acute myelogenous leukemia cells. Science 187, 350-353 (1975).

${ }^{11}$ R. C. Gallo, N. R. Miller, W. C. Saxinger and D. Gillespie, Primate RNA tumor virus-like DNA synthesized endogenously by RNA-dependent DNA polymerase in virus-like particles from fresh human acute leukemic blood cells. Proc. Nat. Acad. Sci. USA 70, 3219-3224 (1973).

${ }^{12} \mathrm{~K}$. Goh and S. N. Swisher, Identical twins and chronic myelocytic leukemia. Arch. Int. Med. 115, 475-478 (1965).

${ }^{13}$ K. Goh, S. N. Swisher and E. C. Herman Jr., Chronic myelocytic leukemia and identical twins. Arch. Int. Med. 120, 214-219 (1967).

${ }^{14}$ N. C. Goodman, R. M. Ruprecht, R. W. Sweet, R. Massey, F. Deinhardt and S. Spiegelman, Viral-related DNA sequences before and after transformation by RNA tumor viruses. Int. $J$. Can. 12, 752-760 (1973).

${ }^{15}$ L. Gross, In: Oncogenic Viruses. pp. 1-991. 2nd Edn. Pergamon Press, Oxford (1970).

${ }^{16}$ S. C. Gulati, R. Axel and S. Spiegelman, Detection of RNA-instructed DNA polymerase and high molecular weight RNA in malignant tissue. Proc. Nat. Acad. Sci. USA 69, 2020-2024 (1972).

${ }^{17}$ B. D. Hall and S. Spiegelman, Sequence complementarity of T2-DNA and T2-specific RNA. Proc. Nat. Acad. Sci. USA 47, 137-146 (1961).

${ }^{18}$ R. Hehlmann, D. Kufe and S. Spiegelman, RNA in human leukemic cells related to the RNA of a mouse leukemia virus. Proc. Nat. Acad. Sci. USA 69, 435-439 (1972).

${ }^{19}$ R. Hehlmann, D. Kufe and S. Spiegelman, Viral-related RNA in Hodgkin's disease and other human lymphomas. Proc. Nat. Acad. Sci. USA 69, 1727-1731 (1972).

${ }^{20}$ G. Henle, W. Henle, P. Clifford, V. Diehl, G. Kafuko, B. Kirya, G. Klein, R. Morrow, G. Munube, P. Pike, P. Tukel and J. Ziegler, Antibodies to Epstein-Barr virus in Burkitt's lymphoma and control groups. J. Nat. Can. Inst. 43, 1147-1157 (1969).

${ }^{21} \mathrm{G}$. Henle, W. Henle and V. Diehl, Relation of Burkitt's tumor-associated herpes-type virus to infectious mononucleosis. Proc. Nat. Acad. Sci. USA 59, 94-101 (1967).

${ }^{22}$ M. Kotler, E. Weinberg, O. Haspel, U. Olshevshy and Y. Becker, Particles released from arginine deprived human leukemic cells. Nature, New Biol. 244, 197 (1973).

${ }^{23}$ D. Kufe, R. Hehlmann and S. Spiegelman, Human sarcomas contain RNA related to the RNA of a mouse leukemia virus. Science 175, 182-185 (1972).

${ }^{24}$ D. Kufe, R. Hehlmann and S. Spiegelman, RNA related to that of a murine leukemia virus in Burkitt's tumors and nasopharyngeal carcinomas. Proc. Nat. Acad. Sci. USA 70, 5-9 (1973).

${ }^{25}$ D. Kufe, I. T. Magrath, J. L. Ziegler and S. Spiegelman, Burkitt's tumors contain particles encapsulating RNA-instructed DNA polymerase and high molecular weight virus-related RNA. Proc. Nat. Acad. Sci. USA 70, 737-741 (1973).

${ }^{26}$ D. W. Kufe, W. P. Peters and S. Spiegelman, Unique nuclear
DNA sequences in the involved tissues of Hodgkin's and Burkitt's lymphomas. Proc. Nat. Acad. Sci. USA 70, 3810-3814 (1973).

${ }^{27}$ T. W. Mak, M. T. Aye, H. Messner, R. Sheinin, J. E. Till and E. A. McCulloch, Reverse transcriptase activity: Increase in marrow cultures from leukemic patients in relapse and remission. Br. J. Can. 29, 433-437 (1974).

${ }^{28}$ T. W. Mak, J. Manaster, A. F. Howatson, E. A. McCulloch and J. E. Till, Particles with characteristics of leukoviruses in cultures of marrow cells from leukemic patients in remission and relapse. Proc. Nat. Acad. Sci. USA 71, 4336 (1974).

${ }^{29}$ C. M. McGrath, P. M. Grant, H. D. Soule, T. Glancy and M. A. Rich, Replication of oncornavirus-like particle in human breast carcinoma cell line, MCF-7. Nature, New Biol. 252, 247-250 (1974).

${ }^{30}$ J. C. Niederman, A. S. Evans, L. Subrahmanyan and R. W. McCollum, Prevalence, incidence and persistence of EB virus antibody in young adults. New Eng. J. Med. 282, 361-365 (1970).

${ }^{31}$ M. Rokutanda, H. Rokutanda, M. Green, K. Fujinaga, R. K. Ray and C. Gurgo, Formation of viral RNA-DNA hybrid molecules by the DNA polymerase of sarcoma-leukemia viruses. Nature, New Biol. 227, 1026-1029 (1970).

${ }^{32}$ R. M. Ruprecht, N. C. Goodman and S. Spiegelman, Determination of natural host taxonomy of RNA tumor viruses by molecular hybridization: Application to RD-114, a candidate human virus. Proc. Nat. Acad. Sci. USA 70, 1437-1441 (1973).

${ }^{33} \mathrm{~J}$. Schlom and S. Spiegelman, Simultaneous detection of reverse transcriptase and high molecular weight RNA unique to oncogenic RNA viruses. Science 174, 840-843 (1971).

${ }^{34}$ J. Schlom, S. Spiegelman and D. H. Moore, RNA-dependent DNA polymerase activity in virus-like particles isolated from human milk. Nature, New Biol. 231, 97-100 (1972).

${ }^{35}$ J. Schlom, S. Spiegelman and D. H. Moore, Detection of high molecular weight RNA in particles from human milk. Science 175, 542-544 (1971)

${ }^{36} \mathrm{C}$. J. Sherr and G. J. Todaro, Primate type $\mathrm{C}$ virus $\mathrm{p} 30$ antigen in cells from humans with acute leukemia. Science 187, 855-856 (1975).

${ }^{37}$ S. Spiegelman, A. Burny, M. R. Das, J. Keydar, J. Schlom, M. Travnicek and $\mathrm{K}$. Watson, Characterization of the products of RNA-directed DNA polymerases in oncogenic RNA viruses. Nature, New Biol. 227, 563-567 (1970).

${ }^{38}$ S. Spiegelman, B. D. Hall and R. Storck, The occurrence of natural DNA-RNA complexes in E. coli infected with $\mathrm{T}_{2}$. Proc. Nat. Acad. Sci. USA 47, 1135-1141 (1961).

${ }^{39}$ S. Spiegelman, D. Kufe, R. Hehlmann and W. P. Peters, Evidence for RNA tumor viruses in human lymphomas including Burkitt's disease. Cancer Res. 33, 1515-1526 (1973).

${ }^{40}$ R. W. Sweet, N. C. Goodman, J.-R. Cho, R. M. Ruprecht, R. R. Redfield and S. Spiegelman, The presence of unique DNA sequences following viral induction of leukemia in mice. Proc. Nat. Acad. Sci. USA 71, 1705-1709 (1974).

${ }^{41} \mathrm{H}$. M. Temin, Nature of the provirus of Rous sarcoma. Nat. Cancer Inst. Monogr. 17, 557-570 (1964).

${ }^{42}$ H. M. Temin and S. Mizutani, RNA-dependent DNA polymerase in virions of Rous sarcoma virus. Nature, New Biol. 226, 1211-1213 (1970).

${ }^{43} \mathrm{G}$. J. Todaro and R. J. Huebner, The viral oncogene hypothesis: New evidence. Proc. Nat. Acad. Sci. USA 69, 1009-1015 (1972).

${ }^{44}$ H. zur Hausen, H. Schulte-Holthausen, G. Klein, W. Henle, G. Henle, P. Clifford and L. Santesson, Epstein-Barr virus DNA in biopsies of Burkitt tumors and anaplastic carcinomas of the nasopharynx. Nature, New Biol. 228, 1056-1058 (1970). 